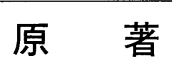

\title{
子宮内膜細胞診における $\mathrm{Ag}-\mathrm{NOR}$ の診断的価值
}

\section{——正常子宮増殖期内膜と高分化型腺癌の比較—}

\author{
国立横浜病院産婦人科 ${ }^{1)}$, 東京医科大学産科婦人科学教室 ${ }^{21}$ \\ 小坂 順治 ${ }^{1)}$ 永田 順子 ${ }^{1)}$ 岡部 一裕 ${ }^{2)}$ 高山 雅臣 ${ }^{2)}$
}

核小体形成領域（nucleolar organizer regions：NOR）はrRNA をコードする DNA ルーブで, これをとりまく非ヒストン蛋白質は好銀性で ( $\mathrm{Ag}-\mathrm{NOR})$, 銀染色により容易に染色できる. AgNOR は細胞の増殖性と関連するため $\mathrm{Ag}-\mathrm{NOR}$ の数がヒトの腫晹の診断や予後判定のうえで有用 であるといわれ，七トの子宮内膜においても内膜増殖症では異型性が増すほど $\mathrm{Ag}-\mathrm{NOR} も$ 増え， 腺癌ではさらに増えるとの報告がある，そこで，エンドサイトまたはウテロブラシを用いた子宮内 膜擦過細胞診標本における Ag-NOR を観察し, 細胞診断学的に有用であるかどうかを検討した. 対象は正常増殖期子宮内膜 20 例と高分化型腺癌 9 例で, エンドサイトまたはウテロブラシで内膜 細胞を採取し, 銀染色を行い 20〜30 個の細胞の核内の $\mathrm{Ag}-\mathrm{NOR}$ の数をカウントした. 正常内膜 では $\mathrm{Ag}-\mathrm{NOR}$ は $1 \sim 6$ 個, 平均 2.68 で, 高分化型腺癌では $2 \sim 7$ 個, 平均 4.78 であり高分化型 腺癌では有意に Ag-NOR の増加が認められた。高分化型腺癌では核異型が軽度で腺癌としての診 断が困難な症例もあり, Ag-NOR は安価で簡単な操作で染色できることから, 細胞診における補 助的診断に有用であると考えられた.

Key words : Endometrial carcinoma-Endometrial cell samples-Ag-NOR-Cytology

\section{I. 緒 言}

核小体形成領域 (nucleolar organizer regions: NOR）はヒトでは第 $13,14,15,21 ， 22$ 染色体にみ られるDNAループで, rRNAをコードしており,

\footnotetext{
$\mathrm{Ag}-\mathrm{NOR}$ counts in endometrial cell samples : comparison between normal endometrium and well-differentiated adenocarcinomas

Junji KOSAKA ${ }^{1)}$, M.D., Junko NAGATA ${ }^{1)}$, M.D., Kazuhiiro $\mathrm{OKABE}^{2)}$, M.D., Masaomi TAKAYAMA ${ }^{2)}$, M.D.

${ }^{11}$ Department of Obstetrics and Gynecology, National Yokohama Hospital

${ }^{2)}$ Department of Obetetrics and Gynecology, Tokyo Medical College

論文別刷請求先：丞 252 横浜市戸塚区原宿 252 国立横浜病 院産婦人科 小坂順治

平成 5 年 2 月 23 日受付

平成 5 年 6 月 18 日受理
}

これを取り巻く非ヒストン蛋白質は好銀性で, 銀染色 により簡単に染色ができることが知られている。これ

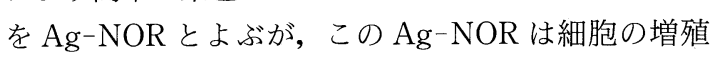
性と関連するため, $\mathrm{Ag}-\mathrm{NOR} の$ 数がヒトの腫湟の診 断や予後判定のうえで有用であるといわれる。 ヒトの 子宮内膜に扔いても月経周期によって $\mathrm{Ag}-\mathrm{NOR}$ は変 化し, 内膜増殖症では異型性が増すほど $\mathrm{Ag}-\mathrm{NOR} の$ 個数は増え, 腺癌ではさらに増えるとの報告占があ る、そこで，エンドサイトまたはウテロブラシを用い た子宮内膜擦過細胞診標本における $\mathrm{Ag}-\mathrm{NOR}$ を観察 し, 細胞診断学的に Ag-NOR が有用であるかどうか を検討した。

\section{II. 対象と方法}

対象は高分化型腺癌と組織学的に診断されたものの 
術前の症例 9 例（表 1 ）で, 術後の診断は I a 期が 7 例， I b 期が 2 例である. 年齢は 48 歳から 56 歳 であった. case 2，5，6 は閉経後の不正出血が主訴で あり case 3，4，7，9 は月経以外の不正出血が主訴で case 8 は過多月経を主訴としていた。対照として，25 歳から 40 歳までの月経周期が 25〜35 日である健康な 女性の増殖期（月経周期第 9 日〜第 12 日）子宮内膜 20 例から得た内膜細胞診標本を用いた。方法は，工 ンドサイトまたはウテロブラシにより子宮内膜細胞を 採取し，スライドグラスに塗抹して $95 \%$ エタノール で固定後, パパニコロー染色を行い, 内膜細胞にマー

表 1 高分化型腺癌

\begin{tabular}{cccl}
\hline \hline case no. & age & stage & clinical symptom \\
\hline 1 & 48 & I a & irregular genital bleeding \\
2 & 52 & I a & postmenoposal bleeding \\
3 & 49 & I b & irregular genital bleeding \\
4 & 48 & I a & irregular genital bleeding \\
5 & 54 & I a & postmenoposal bleeding \\
6 & 56 & I a & postmenoposal bleeding \\
7 & 49 & I b & irregular genital bleeding \\
8 & 55 & I a & hypermenorrhea \\
9 & 50 & I a & irregular genial bleeding \\
\hline
\end{tabular}

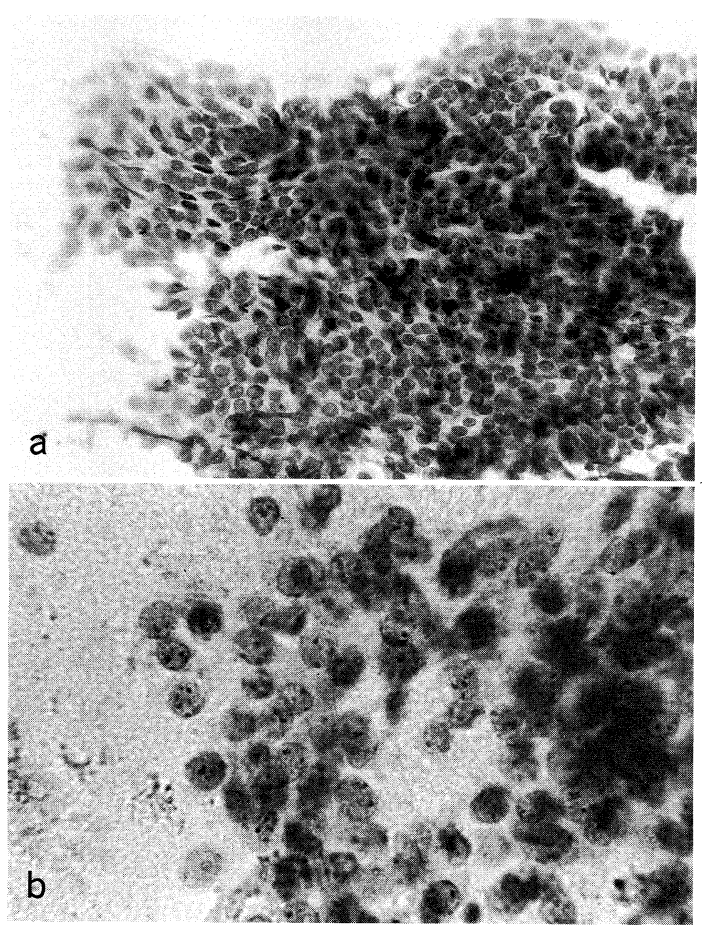

写真 1 正常増殖期内膜細胞. $\mathrm{a}$ ：パパニコロー染色 $(\times$ $200)$, b : Ag-NOR 染色 $(\times 1000)$
クし $10 \%$ 塩酸アルコールで脱色した標本を表 2 に示 す方法で銀染色を行い，スライドグラスを 1000 倍で 検鏡し 20 個から 30 個の細胞の核内のドット数をカウ ントし平均個数を比較した。

\section{III. 結 果}

子宮内膜細胞の $\mathrm{Ag}-\mathrm{NOR}$ は写真 1,2 に示すよう に核内に黒色に点状または小円形状に染色される。写 真 $1 \mathrm{a}$ は正常増殖期内膜のパパニコロー染色で写真 1 b は Ag-NOR 染色である. 写真 $2 \mathrm{a}$ は高分化型腺癌 細胞のパパニコロー染色, $2 \mathrm{~b}$ が $\mathrm{Ag}-\mathrm{NOR}$ 染色であ る. 個々の症例における $\mathrm{Ag}-\mathrm{NOR}$ の個数の平均をま

表 2

1 蒸留水で水和

$22 \%$ ゲラチン加 $1 \%$ 蟻酸水溶液と $50 \%$ 硝酸銀水溶液を $1: 2$ の割合で混合した染色液に室温で 30 分間浸染

3 脱イオン水で 3 回洗浄

4 Mayer ヘマトキシリンで核染色 2 分

5 水洗しアルコール系で脱水後封入

61000 倍で検鏡し 20 個から 30 個の細胞の核内のドット 数をカウント

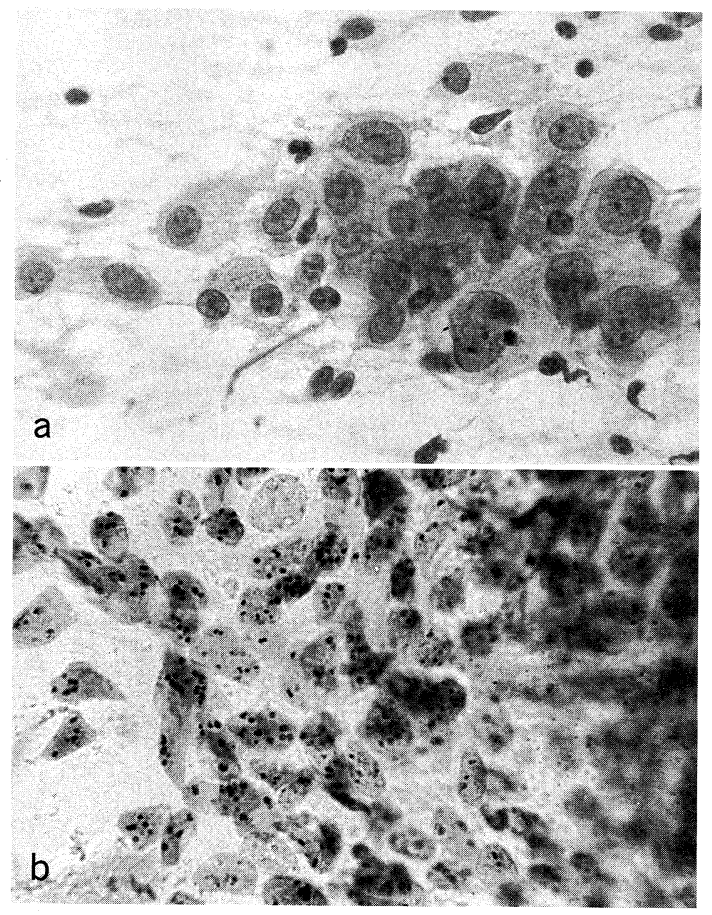

写真 2 高分化型腺癌細胞. $\mathrm{a}$ : パパニコロー染色 $(\times$ $1000), b ： A g-N O R$ 染色 $(\times 1000)$ 
とめたものが表 3 である. 正常性周期で細胞の増殖が 盛んな増殖期における子宮内膜では $\mathrm{Ag}-\mathrm{NOR}$ は 1 6 個, 平均 2.68 で, 7 個以上の $\mathrm{Ag}-\mathrm{NOR}$ 数の核は認め られなかった。一方高分化型腺癌では Ag-NOR は 2 〜 個, 平均 4.78 で $20 \%$ の核に 7 個以上の $\mathrm{Ag}$ NOR が認められ, 正常子宮内膜細胞に比べ有意 $(\mathrm{p}<0.01)$ 的-NOR の増加が認められた。

高分化型腺癌の I a 期, I b 期の $\mathrm{Ag}-\mathrm{NOR}$ 数を比 較すると, case 3, case 7 の I b 期の 2 症例は平均 4.93 で I a 期の症例に比し例数は少ないが高値を示 す傾向がみられた。

以上の成績より高分化型腺癌では正常子宮内膜に比 し有意に Ag-NOR 数の増加が認められ, 癌化の指標 を示唆する所見と考えられる。

\section{IV. 考察}

腫瘍の増殖能を知ることは, 予後の推定や治療法の 選択, 覀性度の診断のために重要であり, 増殖能の指 標として Ki-67やPCNA（Proliferating Cell Nuclear Antigen) そして Ag-NORなどが知られてい る. 澤田ら ${ }^{2)}$ は子宮体部上皮性腫瘍ならびに関連病変 において内膜增殖症と腺癌における PCNA の標識率 を比較し, 内膜増殖症では PCNA 標識率は $0 \%$ であ ったのに対し腺癌では $24 \%$ であると述べ体部悪性腫 瘍に扔いては PCNA が悪性度の指標になることを示 唆している. Ag-NORについては, 腫瘍の悪性変化 に伴い $\mathrm{Ag}-\mathrm{NOR}$ が増加し䛦断的価值もありうること

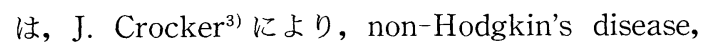
skin neoplasms, mesothelioma などについて報告さ れている。婦人科の腫瘍においても腫瘍の悪性度によ り Ag-NOR が変化するという報告は多くみられる。

M. Egan ら ${ }^{4} は$, CIN (Cervical Intraepithelial Neoplasm）において CIN 3 の Ag-NOR がCIN 1 あるい は CIN 2 に比べ増加すると報告して抢り, J.F. Darne ら ${ }^{5}$ は，子宮頸部の invasive adenocacinomaにおけ る Ag-NOR が AIS (adenocarcinoma in situ) に比

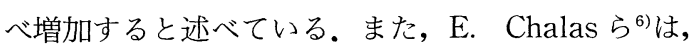
endometriosis, atypical endometriosis および clear cell carcinoma と endometrioid carcinomaにおける $\mathrm{Ag}-\mathrm{NOR}$ を検討し, 悪性化に伴い $\mathrm{Ag}-\mathrm{NOR}$ の数が 増加することを指摘している。このようなことからあ る組織について Ag-NOR の数をカウントすることに より，その悪性度を推測することがある程度可能であ
表 3

\begin{tabular}{cc|cc}
\hline \multicolumn{2}{c|}{$\begin{array}{c}\text { 正常子宮内膜 } \\
\text { case no. }\end{array}$} & \multicolumn{2}{|c}{$\begin{array}{c}\text { 高分化型腺癌 } \\
\text { average }\end{array}$} \\
\hline 1 & 2.68 & 1 & 4.85 \\
2 & 2.82 & 2 & 4.83 \\
3 & 3.05 & 3 & 4.93 \\
4 & 3.15 & 4 & 4.43 \\
5 & 2.52 & 5 & 4.89 \\
6 & 2.48 & 6 & 4.43 \\
7 & 2.72 & 7 & 4.93 \\
8 & 2.40 & 8 & 4.98 \\
9 & 2.40 & 9 & 4.78 \\
10 & 3.25 & & \\
11 & 3.20 & & \\
12 & 2.50 & & \\
13 & 2.40 & & \\
14 & 2.40 & & \\
15 & 2.85 & & \\
16 & 3.00 & & \\
17 & 3.05 & & \\
18 & 2.24 & & \\
19 & 2.20 & & \\
20 & 2.35 & & \\
\hline
\end{tabular}

正常子宮内膜：mean；2.68, SD；0.299

高分化型腺癌：mean；4.78, SD；0.209

ると考えられ，Ag-NORにより悪性度の診断もでき るのではないか考えられる。

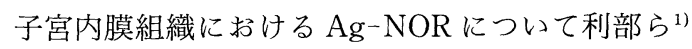
は, 老人萎縮内膜, 正常増殖期㧍よび分泌期内膜, 子 宮内膜増殖症, 子宮内膜癌について比較し, 増殖内膜 の $\mathrm{Ag}-\mathrm{NOR}$ が $2.93 \pm 0.83$ 個であるのに対し G 1 腺 癌では $3.87 \pm 1.34$ 個であり, 増殖症においても異型 性が増すほど $\mathrm{Ag}-\mathrm{NOR}$ が増えると報告している。ま た, 玉舎7) 同様に子宮内膜腺における $\mathrm{Ag}-\mathrm{NOR}$ が 月経周期で変動し, 増殖期には増え分泌期には減少す ること, 内膜癌では増加し高分化型〜中分化型腺癌で は MPA（酢酸メドロキシプロゲストロン）投与によ り減少することなどを指摘している。このように，子 宮内膜に抢ける $\mathrm{Ag}-\mathrm{NOR}$ は月経周期によって変化す るだけでなく, 癌化により増加することが知られてい る.

近年子宮体癌は増加傾向にあり, 体癌の早期発見の ための診断法としての子宮内膜細胞診の役割はますま す重要になっている. 子宮内膜細胞診における体癌の 発見率は蔵本 ${ }^{8}$ によれば初回の細胞診では約 $83 \%$ で あるが, 分化型腺癌 (G 1，I期）では偽陰性率が約 37\% と高い. G1 腺癌では核異型のたいへん乏しい例 
があり, 細胞診標本においても核形の不整, 核の大小 不同，核小体の出現などの癌細胞としての特徵がはっ きりしないことがあるため, 偽陰性率が高くなると考 えられる。この偽陰性率は繰り返し細胞診を行うこと により低めることができるが，一般の検診などで偽陰 性となった場合にはその後の follow up に問題を生じ る可能性が危惧される.今回のわれわれの研究では内 膜細胞診に扔ける $\mathrm{Ag}-\mathrm{NOR}$ が G 1 腺癌で有意に増加 することが示された。さらに Ag-NOR は Ki-67や PCNA などと比較して大変安価で, しかも簡単な操 作で 40〜50 分の間に染色できるため, 細胞診におけ る補助的診断に有用であり，特に大量の検体を処理す る場合にでも positive か negative かの診断の参考と なりうると考えられた。

\section{V. 結 語}

エンドサイトまたはウテロブラシを用いて外来にお ける通常の方法で採取した子宮内膜細胞診標本におい て, G 1 腺癌細胞では正常子宮増殖期内膜細胞に比 べ，有意に Ag-NOR の増加が認められた．高分化型 腺癌では核異型が少なく診断が困難である場合もあ り，そのような場合には偽陰性となることがあるが， $\mathrm{Ag}-\mathrm{NOR}$ は安価で簡単な操作で染色できるため, 細 胞診における補助的診断に有用であると考えられた。

\section{Summary}

Nucleolar organizer regions are loops of DNA, which in humans are found on chromosomes 13, 14, 15, 21, and 22, and code for ribosomal RNA. They are associated with nonhistone nucleoproteins, which can be stained with silver (AgNOR). An increased number of $\mathrm{Ag}-\mathrm{NOR}$ has been observed in many malignancies and $\mathrm{Ag}-\mathrm{NOR}$ counts are useful for tumor diagnosis. Ag-NOR were counted in two groups of women: those with endometrial well-differentiated adenocarcinomas $(n=9)$ and another group with normal endometrium in the proliferative phase $(n=20)$. The en- dometrial cell samples were taken with an endocyte or uterobrush. Mean Ag-NOR counts were 4.81 in well-differentiated adenocarcinomas and 2.68 in normal proliferative phase endometrium. The results were analyzed and the number of Ag-NOR per nucleus was significantly higher in the endometrial adenocarcinoma cells than in the normal proliferative phase endometrial cells $(\mathrm{p}<0.01) . \mathrm{Ag}-\mathrm{NOR}$ counts provide useful information, are inexpensive, can be obtained from endometrial cell samples and may aid in the clinical diagnosis of patints with endometrial well-differentiated adenocarcinomas.

\section{文 献}

1）利部輝雄, 佐藤昌之, 井筒俊彦 - 他 : 七ト子宮内膜の核 小体形成領域所見，日産婦誌，43：791〜 792, 1991.

2）澤田益臣・他：婦人科腫瘍並びに関連病変における Proliferating Cell Nuclear Antigen (PCNA) の免疫 組織学的検討, 日産婦誌, $44: 181 \sim 187,1992$.

3) Crocker, J. : Nucleolar organizer regions In Underwood JCE ed. Current Topics in Pathology, 92 149, Springer Verlag, Berlin, 1989.

4) Egan, M., Freeth, M. and Crocker, J. et al. : Relationship between intraepithelial neoplasia of the cervix and the size and number of nucleolar organizer regions, Gynecol. Oncol. $36:$ 30 33, 1990.

5) Darne, J.F., Polacarz, S.V. and Sheridan, E. et al. : Nucleolar organizer regions in adenocarcinoma in situ and invasive adenocarcinoma of the cervix, J. Clin. Pathol. $43:$ 657 660, 1990.

6) Chalas, E., Chumas, J. and Barbieri, R. : Nucleolar organizer regions in endometriosis, atypical endometriosis, and clear cell and endometrioid carcinomas, Gynscol. Oncol. 40：260〜263, 1991.

7）玉舎輝彦：核小体形成領域（体）の臨床, 産婦治療, $63: 453 \sim 459,1991$.

8）蔵本博行：カラーアトラス子宮体癌検診, 11 , 医歯薬出 版, 東京, 1989 . 